\title{
PROBLEMATIKA PELAKSANAAN PENDAFTARAN TANAH MELALUI PENDAFTARAN TANAH SISTEMATIS LENGKAP DI KOTA BATU
}

\author{
Isdiyana Kusuma Ayu \\ Fakultas Hukum Universitas Islam Malang \\ J1. MT Haryono Nomor No. 193, Malang, Jawa Timur, Indonesia \\ E-mail : isdiyana@unisma.ac.id
}

\begin{abstract}
Systematic and Complete Land Registration (PTSL) is a program organized by the Government to assist the public in obtaining the certificate of the land. Batu City is one of the cities in Indonesia that follow to help communities that PTSL majority among those yet to register their land to Office land Batu City. The purpose of this research is to describe the implementation of PTSL in Batu City and analyze its land registry through systematic land registration in Batu City and the efforts complete. The method used in this research is juridical-empiric research method using juridical sociological approach. The role of Councilor and community groups are very important in the implementation of PTSL in Batu City. Problems found in the implementation of PTSL in Batu City, namely the object ground warranted, a period of physical and juridical data announcement 14 working days, an affidavit of Ownership in good faith as a replacement deed of passage, delay in paying taxes of the land, the lack of human resources, and Absentee Land and The forbidden land in Batu City.
\end{abstract}

\section{Keywords : First Registration, Single Mapping, Systematic}

\begin{abstract}
Abstrak
Pendaftaran Tanah Sistematis Lengkap (PTSL) merupakan salah satu program yang diselenggarakan oleh Pemerintah untuk membantu masyarakat dalam memperoleh sertipikat tanah. Kota Batu merupakan salah satu kota di Indonesia yang mengikuti PTSL untuk membantu masyarakat yang mayoritas di antara mereka belum mendaftarkan tanahnya ke kantor pertanahan Kota Batu. Tujuan penelitian ini yaitu mendeskripsikan pelaksanaan PTSL di Kota batu dan menganalisis problematika pendaftaran tanah melalui pendaftaran tanah sistematis lengkap di Kota Batu dan upaya penyelesaiannya. Metode penelitian yang digunakan dalam penelitian ini yaitu penelitian yuridis-empiris dengan pendekatan yuridis-sosiologis. Peran perangkat Desa dan kelompok masyarakat sangat penting dalam pelaksanaan PTSL di Kota Batu. Problematika yang ditemukan dalam pelaksanaan PTSL di Kota Batu yaitu Obyek tanah yang dijaminkan, Jangka waktu pengumuman data fisik dan yuridis 14 hari kerja, Surat Pernyataan Kepemilikan dengan Itikad Baik sebagai pengganti akta peralihan,
\end{abstract}


Penundaan Pembayaran Pajak Peralihan Hak Atas Tanah, Sumber daya manusia yang kurang, Tanah Absentee dan Tanah Terlarang di Kota Batu.

\section{Kata Kunci : Pendaftaran Pertama Kali, Peta Tunggal, Sistematis}

\section{A. PENDAhUluan}

Pendaftaran tanah di Indonesia merupakan hal yang penting harus dilakukan oleh masyarakat untuk memperoleh kepastian hukum terhadap tanah yang dimilikinya. Kepastian hukum tersebut telah dijamin oleh Pemerintah sesuai dengan Pasal 19 Undang-Undang Nomor 5 tahun 1960 tentang Pokok-Pokok Agraria. Selanjutnya, Pemerintah untuk memberikan sarana dalam memberikan jaminan kepastian hukum tersebut dengan menerbitkan Peraturan Pemerintah Nomor 24 tahun 1997 tentang Pendaftaran Tanah (untuk selanjutnya disebut dengan PP 24 Tahun 1997). Pasal 3 huruf a PP No 24 Tahun 1997 menyebutkan bahwa Pendaftaran Tanah bertujuan untuk memberikan kepastian hukum dan perlindungan hukum kepada pemegang hak atas suatu bidang tanah, satuan rumah susun, dan hak-hak lain yang terdaftar agar dengan mudah dapat membuktikan dirinya sebagai pemegang hak yang bersangkutan.

Salah satu kegiatan pendaftaran tanah meliputi pendaftaran tanah untuk pertama kali. ${ }^{1}$ Pendaftaran tanah untuk pertama kali merupakan pendaftaran tanah yang obyeknya belum didaftarkan berdasarkan Peraturan Pemerintah Nomor 10 Tahun 1961 tentang Pendaftaran Tanah dan PP 24 Tahun 1997. Kegiatan pendaftaran ini dilakukan dengan dua cara yaitu secara sistematis dan sporadik. Pendaftaran tanah secara sistematis merupakan kegiatan pendaftaran tanah yang dilakukan secara serentak oleh Pemerintah dalam wilayah atau bagian wilayah suatu desa atau kelurahan.

Implementasi dari pendaftaran tanah pertama kali secara sistematis yaitu Pendaftaran Tanah Sistematis Lengkap (selanjutnya disebut PTSL). PTSL merupakan kegiatan pendaftaran tanah untuk pertama kali yang dilakukan secara serentak bagi semua obyek pendaftaran tanah di seluruh wilayah Republik Indonesia dalam satu wilayah desa/kelurahan atau nama lainnya yang setingkat dengan itu, yang meliputi pengumpulan dan penetapan kebenaran data fisik dan data yuridis mengenai satu atau beberapa obyek pendaftaran tanah untuk keperluan pendaftarannya. ${ }^{2}$ PTSL diatur dalam Peraturan Menteri Agraria dan Tata Ruang/Kepala Badan Pertanahan Nasional Republik Indonesia Nomor 6 Tahun 2018 tentang Pendaftaran Tanah Sistematis Lengkap yang merupakan perubahan dari Peraturan Menteri Agraria dan Tata Ruang/Kepala Badan Pertanahan Nasional Nomor 35 Tahun 2016 sebagaimana telah diubah dengan Peraturan Menteri Agraria dan

\footnotetext{
${ }^{1}$ Pasal 11 Peraturan Pemerintah Nomor 24 Tahun 1997 tentang Pendaftaran Tanah

2 Pasal 1 angka 2 Peraturan Menteri Agraria dan Tata Ruang/Kepala Badan Pertanahan Nasional Republik Indonesia Nomor 6 Tahun 2018 tentang Pendaftaran Tanah Sistematis Lengkap.
} 
Tata Ruang/Kepala Badan Pertanahan Nasional Nomor 1 Tahun 2017 tentang Perubahan atas Peraturan Menteri Agraria dan Tata Ruang/Kepala Badan Pertanahan Nasional Nomor 35 Tahun 2016 tentang Percepatan Pelaksanaan Pendaftaran Tanah Sistematis Lengkap.

Pelaksanaan PTSL merupakan langkah Pemerintah ingin memberikan kepastian hukum dan perlindungan hukum kepada masyarakat dalam menguasai suatu bidang tanah. PTSL yang mulai dilaksanakan berbeda dengan program pemerintah sebelumnya seperti Proyek Administrasi Pertanahan (PAP), Land Management and Policy Development Project (LMPDP) atau Proyek Ajudikasi, Larasita, dan Program Nasional Agraria (Prona). PTSL berbeda dengan programprogram sebelumnya karena Presiden memantau, mengevaluasi bahkan berperan langsung dalam pembagian sertifikatnya kepada masyarakat. ${ }^{3}$

Pelaksanaan PTSL secara umum terdapat penyimpangan dengan proses pendaftaran tanah yang diatur dalam PP 24 Tahun 1997, khususnya terkait administrasi yang tidak perlu adanya akta peralihan. Selain itu, permasalahan lainnya antara lain penundaan pembayaran pajak atas tanah yang dapat dilakukan dikemudian hari, sumber daya manusia yang belum maksimal, tanah yang sedang dijaminkan, serta tanah yang masih dalam sengketa.

Salah satu daerah di Indonesia yang mengikuti PTSL yaitu Kota Batu. Kota Batu yang terletak di Provinsi Jawa Timur dengan luas wilayah 19.908,72 Ha dengan jumlah 3 kecamatan, 4 kelurahan, dan 24 desa $^{4}$. Pada tahun 2018, Kota Batu ditargetkan oleh Pemerintah Pusat untuk mensertifikatkan 10.000 bidang tanah. Total sertifikat yang diterbitkan dari program PTSL disebar yaitu 3.000 untuk Desa Oro-oro Ombo, 4.000 untuk Desa Torongrejo, 1.000 untuk Desa Gunungsari, dan 2.000 untuk Desa Dadaprejo. Kota Batu yang menjadi salah satu tempat pelaksanaan PTSL tersebut maka perlu diadakan penelitian terkait pelaksanaan PTSL di Kota Batu dan mengetahui problematika pendaftaran tanah melalui pendaftaran tanah sistematis lengkap di Kota Batu dan upaya penyelesaiannya.

\section{B. RUMUSAN MASALAH}

Rumusan masalah dalam penelitian ini adalah:

1. Bagaimanakah pelaksanaan pendaftaran tanah melalui pendaftaran tanah sistematis lengkap di Kota Batu?

2. Apakah kendala yang ada dalam pendaftaran tanah melalui pendaftaran tanah sistematis lengkap di Kota Batu?

${ }^{3}$ Dian Aries Mujiburohman, Potensi Permasalahan Pendaftaran Tanah Sistematik Lengkap (PTSL), Bhumi, Volumen 4 Nomor 1 Mei 2008, hlm 90.

${ }^{4}$ Badan Pusat Statistik Kota Batu, statistik daerah daerah kota batu 2016, batu, 2016, hlm. 1. 


\section{METODE PENELITIAN}

Kajian ini menggunakan penelitian yuridis empiris dengan pendekatan yuridis sosiologis. Pendekatan yuridis dalam penelitian ini bertujuan untuk menganalisis Peraturan Menteri Agraria dan Tata Ruang/ Kepala Badan Pertanahan Nasional Nomor 6 Tahun 2018 tentang Pendaftaran Tanah Sistematis Lengkap, kemudian secara sosiologis dengan melihat pelaksanaan peraturan tersebut di masyarakat Kota Batu yang termasuk sebagai peserta dari proses pendaftaran tanah melalui PTSL yang diselenggarakan oleh Kantor Pertanahan Kota Batu.

\section{PEMBAHASAN}

\section{Pelaksanaan Pendaftaran Tanah Melalui Pendaftaran Tanah Sistematis Lengkap di Kota Batu}

PTSL merupakan program yang ditawarkan oleh Kantor Pertanahan Kota Batu kepada semua desa yang berada di Kota Batu. Kota Batu ditargetkan sebanyak 10.000 bidang untuk diberikan sertifikat. Desa dan kelurahan yang mengikuti program PTSL hanya 4 Desa antara lain 3.000 untuk Oro-oro Ombo, 4.000 untuk Desa Torongrejo, 1.000 untuk Desa Gunungsari, dan 2.000 untuk Desa Dadaprejo untuk tahun 2018. Sedangkan pada tahun 2019, penerbitan sertifikat akan ditingkatkan menjadi 19.000 bidang tanah. Pada tahun 2018, Kantor Pertanahan Kota Batu telah melaksanakan program ini sejak bulan Januari dan ditargetkan selesai pada tanggal 31 Oktober 2018. Ketika pada tanggal tersebut, pelaksanaan PTSL tahun 2018, belum selesai akan diberi tenggang waktu selama 3 bulan, berarti pada bulan Januari 2019, Kantor Pertanahan Kota Batu harus menyelesaikan PTSL periode 2018.

Kepala Desa Oro-Oro Ombo, Bapak Wiweko, menjelaskan bahwa Desa Oro-Oro Ombo merupakan salah satu desa yang mengikuti PTSL. Hasil wawancara dengan Bapak Wiweko, PTSL merupakan program Pemerintah yang bersifat penawaran. Sehingga ketika suatu desa yang sudah ditawarkan oleh Kantor Pertanahan Kota Batu namun menolaknya tidak akan mendapatkan sanksi dari Pemerintah. Desa Oro-oro Ombo mengajukan desanya untuk mengikuti PTSL karena Desa Oro-Oro Ombo memiliki tujuan wisata yang didatangi oleh wisatawan lokal maupun asing ketika mengunjungi Kota Malang. Alasan lainnya yaitu bentuk kepedulian Pemerintah Desa terhadap masyarakat Desa Oro-Oro Ombo, khususnya dalam hal kepemilikan sertifikat tanah. Alasan yang sama juga diberikan oleh Lurah Dadaprejo, Bapak Abdul Salam, bahwa penerimaan program PTSL di Kelurahan Dadaprejo bertujuan untuk mempermudah masyarakat untuk memperoleh sertifikat tanah dengan mudah dan murah agar masyarakat memiliki kepastian hukum terhadap tanah yang dikuasainya dan mampu meningkatkan harga tanah ketika akan dijaminkan di perbankan. 
Kantor Pertanahan Kota Batu memberikan kesempatan 4000 bidang tanah yang belum bersertifikat di Desa Oro-Oro Ombo untuk mengikuti PTSL. Namun, hanya 3.300 bidang yang disanggupi oleh Desa Oro-oro Ombo. Luas Desa Oro-Oro Ombo yaitu 42 ha dan bidang yang mengikuti PTSL sebanyak 3.300 bidang dan bidang yang sudah masuk ke BPN sebesar 2.400 bidang yang sudah terkumpul sejak bulan Maret hingga Juli 2018. Sedangkan sisanya sebesar 900 bidang masih berada di Pemohon atau RT/RW.Sisa bidang tanah di Desa OroOro Ombo juga pernah mengikuti Program yang serupa dengan PTSL yaitu PRODA pada tahun 2016 yang diperuntukkan warga kurang mampu sebesar 100 bidang dan 2017 untuk Ketua RT dan RW setempat.

Kelurahan Dadaprejo ditargetkan sebesar 2000 bidang dengan rincian 1700 bidang tanah sudah terkumpul datanya di Kantor Pertanahan Kota Batu, 50 bidang tanah sudah selesai diterbitkan sertifikat oleh Kantor Pertanahan Kota Batu, dan sisanya masih dalam proses pengumpulan data oleh Kelompok Masyarakat setempat. Total kepemilikan tanah di Kelurahan Dadaprejo sebesar 2.299 bidang, tahun 2007 Kelurahan Dadaprejo memiliki Program SMS (Swadaya Murni Sertifikasi) sebanyak 190 bidang dan sisanya terdapat kemungkinan dilakukan pendaftaran secara sporadik.

Biaya yang dikeluarkan oleh Pemohon yaitu sebesar Rp. 150.000 (seratus lima puluh ribu rupiah) dengan rincian 1 (satu) materai dan 3 (tiga) buah patok. Biaya sebesar Rp. 150.000 merupakan biaya yang ditetapkan oleh Pemerintah yang diatur dalam Keputusan Bersama Menteri Agraria dan Tata Ruang/ Kepala Badan Pertanahan Nasional, Menteri Dalam Negeri, dan Menteri Desa, Pembangunan Daerah Tertinggal dan Transmigrasi Nomor 25/SKB/V/2017, Nomor 590-3167A Tahun 2017, Nomor 34 Tahun 2017 tentang Pembiayaan Persiapan Pendaftaran Tanah Sistematis, selanjutnya disebut SKB 3 Menteri. Jika lebih dari ketentuan yang ada maka biaya akan dibebankan kepada peserta PTSL.Sosialisasi kegiatan PTSL oleh Pihak BPN Kota Batu yang dilaksanakan oleh BPN juga dihadiri oleh pihak Kepolisian, Kejaksaan, dan Pihak dari desa, serta masyarakat setempat.

Pihak-pihak yang berperan dalam PTSL di lingkungan Desa Oro-oro Ombo dilakukan oleh Panitia Desa terdiri dari Karang Taruna, Tokoh Pemuda, dan Tokoh Masyarakat, khususnya Ketua RT dan RW. Ketiga elemen tersebut mendapatkan Surat Keputusa dari Kepala Desa untuk memperkuat tugas mereka ketika mendata di masyarakat. Surat Keputusan tersebut menjadi dasar para tim agar ketika mengambil data di masyarakat tidak disalahartikan oleh masyarakat. Selaint itu, peran Ketua RT dan RW yaitu mengumpulkan berkas, mendampingi pada saat pengukuran, dan menyelesaikan masalah yang ada masyarakat desa yang masuk dalam satu wilayah. Ketika permasalahan tersebut tidak dapat 
diselesaikan dalam lingkup wilayah RT/RW maka akan dibawa ke Kantor Desa untuk diselesaikan oleh Perangkat Desa yang terkait.

Permasalahan yang terjadi dalam pelaksanaan PTSL di Desa Oro-Oro Ombo yaitu terdapat beberapa tanah yang dimiliki oleh masyarakat yang batas tanahnya berdampingan dengan jalan atau dengan tanah yang belum dibangun bangunan. Selain itu, permasalahan yang muncul yaitu beberapa warga di Desa Oro-oro Ombo yang sudah memiliki surat kepemilikan tanah seperti Petok D menjaminkannya di perbankan yang menyebabkan bukti kepemilikan yang tidak dapat diperlihatkan.

PTSL yang diselenggarakan di Kelurahan Dadaprejo juga dilakukan oleh Kelompok Masyarakat yang terdiri dari Ketua RT dan Ketua RW serta Tokoh Masyarakat. Kelurahan Dadaprejo sudah membagi tugas antara pihak kelurahan dengan Kelompok Masyarakat. Kelompok masyarakat memiliki tugas untuk pengumpulan data dari masyarkat, sedangkan pihak Kelurahan membantu kelengkapan administrasi seperti krawangan desa, penertiban administrasi ketika ditemukan perbedaan nama pemohon dengan administrasi lainnya yang terkait, dan surat keterangan waris ketika pemilik tanahnya sudah meninggal. Selain itu, tugas dari Kelompok Masyarakat di Kelurahan Dadaprejo juga diberikan Surat Keputusan dari Lurah sebagai dasar tugas yang berkewajiban untuk mengumpulkan berkas dari masyarakat sebagai persyaratan pelaksanaan PTSL. Koordinator pelaksanaan PTSL di Kelurahan Dadaprejo yaitu Kasi Pemerintahan Ketentraman dan Ketertiban, Didik Handriwahyudi, SH, atas dasar SK yang dikeluarkan oleh Kantor Pertanahan.

Kelurahan Dadaprejo juga memiliki permasalahan dalam pelaksanaan PTSL yaitu eKTP yang dimiliki oleh masyarakat ternyata belum dapat diakses oleh Kantor Pertanahan Kota Batu dan masyarakat Dadaprejo yang kurang proaktif terhadap pelaksanaan PTSL karena masyarakat Dadaprejo didominasi oleh masyarakat yang tidak bekerja. Rincian penduduk di Kelurahan Dadaprejo yaitu sebanyak 1.663 warga, 1.182 warga yang bekerja sebagai mengurus rumah tangga, pelajar/mahasiswa sebanyak 1.078 warga, 923 warga sebagai karyawan swasata, 561 warga sebagai petani/pekebun, dan sisanya beragam. Berdasarkan data terebut dapat diketahui bahwa masyarakat Dadaprejo masih sedikit memiliki rasa kepedulian untuk mensertifikatkan tanah yang dikuasainya.

Berdasarkan penelitian tersebut maka dapat diketahui bahwa peran Kantor Desa OroOro Ombo dan Kelurahan Dadaprejo memiliki persamaan yaitu mensosialisasikan PTSL, membuatkan Surat Keputusan penunjukkan pihak pelaksana PTSL di masing-masing wilayah, membuatkan kelengkapan administrasi, dan sebagai mediator ketika terjadi suatu permasalahan dalam pelaksanaan PTSL. Hal ini juga menjelaskan bahwa peran yang dimiliki Kantor Desa ataupun Kelurahan hanya sebagai pelengkap, sedangkan yang memiliki peran penting dalam kelancaran PTSL yaitu Kelompok Masyarakat dalam pengumpulan data. 
Bapak Agus Harianto, Kasi Hubungan Hukum Pertanahan Kantor Pertanahan, menjelaskan bahwa dasar hukum PTSL yaitu Instruksi Presiden Nomor 2 Tahun 2018, SKB 3 Menteri, dan Perment Nomor 6 Tahun 2018 tentang Pendaftaran Tanah Sistematik Lengkap. Latar belakang pelaksanaan PTSL yaitu sebagai bentuk pendataan tanah yang masih belum selesai sehingga dapat mewujudkan peta tunggal terhadap tanah di Indonesia. Tugas utama dari PTSL yaitu memberikan sertifikat tanah kepada masyarakat dan pendaftaran ini juga ditujukan kepada pengusaha yang termasuk Usaha Menengah Kecil (UMK) sebesar 250 bidang dari 10.000 bidang yang ditargetkan di Kota Batu. Ketika Pemohon PTSL merupakan pengusaha UMK maka Kantor Pertanahan Kota Batu akan dibantu oleh Departemen Koperasi untuk pemberkasan.

Alur pelaksanaan PTSL di Kota Batu yaitu penyuluhan di desa-desa yang berpartisipasi dilanjutkan dengan pengumpulan data yuridis dan yuridis. Selanjutnya hasil pemberkasan tersebut diberikan kepada Panitia A untuk diteliti. Penelitian Panitia A juga termasuk dalam pengukuran tanah yang akan didata. Setelah itu sertifikat akan diterbitkan oleh Kantor Pertanahan dengan dilanjutkan penyerahan kepada Peserta PTSL. Kantor Pertanahan yang telah selesai menyerahkan sertifikat tanah kepada masyarakat, Kantor Pertanahan memiliki kewajiban untuk melakporkan hasil kerjanya ke Kantor Wilayah Pertanahan.

Kota Batu telah ditargetkan mensertifikatkan tanah sebanyak 10.000 bidang. Apabila Kantor Pertanahan Kota Batu tidak dapat menyelesaikan program tersebut akan diberikan waktu tambahan selama tiga bulan. Namun, setelah tiga bulan, kantor pertanahan masih belum juga dapat menyelesaikan program tersebut akan dikenakan sanksi administratif berupa perpindahan wilayah kerja bagi aparat yang terkait dalam pelaksanaan PTSL di Kantor Pertanahan Kota Batu. Namun, ketika target yang telah ditetapkan oleh Pemerintah ternyata melebihi jumlahnya maka kelebihan tersebut akan diikutkan di anggaran selanjutnya.

\section{Kendala dalam Pelaksanaan Pendaftaran Tanah Melalui Pendaftaran Tanah Sistematis Lengkap di Kota Batu dan Upaya Penyelesaiannya}

Permasalahan yang timbul dari pelaksanaan PTSL dapat berupa batas tanah, obyek sedang dijaminkan di bank, dan obyek sudah bersertifikat namun didaftarkan kembali. Ketika dalam proses pelaksanaan PTSL di Kota Batu timbul suatu permasalahan maka bidang tersebut akan ditunda hingga masalah tersebut terselesaikan. Dalam hal ini peran desa sangat diperlukan karena pihak desa yang menyaring obyek-obyek yang bermasalah ataupun tidak. Berikut merupakan problematika dan upaya penyelesaiannya yang ditemukan dalam pelaksanaan PTSL di Kota Batu:

a. Obyek Tanah dalam Penjaminan di Perbankan 
Ketika permasalahan berkaitan dengan obyek yang dijaminkan di bank maka Pemohon akan dimintakan surat pernyataan bahwa setelah sertifikat tersebut telah ditebitkan Kantor Pertanahan Kota Batu akan dikembalikan lagi ke perbankan. Selain itu, sertifikat tanah tersebut akan diberi tanda sebagai bentuk adanya penjaminan obyek tersebut. Penyerahan juga tidak diberikan kepada pemilik tanah melainkan akan diberikan kepada pihak bank sebagai kreditur.

b. Jangka waktu pengumuman data fisik dan yuridis

Bapak Agus menjelaskan bahwa PTSL memberikan kemudahan dan keringanan kepada masyarakat untuk memperoleh sertifikat tanah. Pengumuman terkait kepemilikan tanah dalam program PTSL hanya 14 hari kalender dan tidak memerlukan akta peralihan. Akta peralihan diubah dengan surat pernyataan pengakuan tanah. Legalitas yang diberikan juga sama sehingga tidak perlu diragukan lagi kepastian hukum yang ada. Meskipun hanya 14 hari kalender untuk pengumuman kepemilikan tanah, sengketa yang dimunculkan akan mudah diatasi karena program ini bersifat serentak. Sertifikat tanah yang diterbitkan dari proses PTSL tidak ada perbedaan dengan sertifikat yang diterbitkan secara sporadik. Pengumuman data fisik dan data yuridis yang dipercepat merupakan bentuk lain penyimpangan aturan dalam PP 24 Tahun 1997. Pengumuman merupakan implementasi asas publisitas dalam pembuktian kepemilikan tanah. Pengumuman data fisik dan data yuridis dalam pelaksanaan PTSL hanya 14 hari kalender berdasarkan ketentuan Permen Agraria No 6 Tahun 2018. Bapak Agus menjelaskan bahwa waktu pengumuman data fisik dan data yuridis selama 14 hari kalender dianggap cukup karena kegiatan PTSL merupakan kegiatan besar dan diketahui oleh orang banyak sehingga ketika ada pihak yang tidak setuju akan data tersebut dapat langsung mengajukan keberatan kepada Kantor Pertanahan.

Jangka waktu 14 hari kalender memang tergolong singkat dan efisien mengingat bahwa PTSL merupakan kegiatan pemerintah yang memiliki target setiap periodenya. Namun, permasalahan muncul ketika aturan tersebut bertentangan dengan aturan yang diatasnya yaitu PP 24 Tahun 1997 yang memberikan jangka waktu pengumuman data fisik dan data yuridis untuk tanah yang belum bersertifikat selama 60 hari kerja. Berdasarkan asas lex superior derogat legi inferior maka aturan yang digunakan yaitu PP 24 Tahun 1997 tentang Pendaftaran Tanah karena memiliki kedudukan yang tinggi bila dibandingkan Peraturan Menteri Agraria Nomor 6 Tahun 2018.

\section{a. Surat Pernyataan Kepemilikan dengan Itikad Baik}

Bapak Agus juga menjelaskan bahwa Permen Agraria No 6 Tahun 2018 telah mengenyampingkan PP 24 Tahun 1997. Bentuk pengecualian dari PP 24 Tahun 1997 dalam pelaksanaan PTSL yaitu tidak menggunakan akta peralihan ketika memang ada peralihan hak 
atas tanah sebelumnya. PP 24 Tahun 1997 menjelaskan bahwa setiap peralihan hak atas tanah yang dialihkan wajib menggunakan akta yang dibuat oleh Pejabat Pembuat Akta Tanah (PPAT). Namun, untuk mengefisienkan waktu dan administrasi maka akta tersebut diganti dengan surat pernyataan kepemilikan tanah bermaterai yang dibuat oleh Pemohon. Sebenarnya akta PPAT menjadi salah satu upaya Pemerintah memberikan kepastian hukum hukum adanya peralihan hak atas tanah karena akta yang diterbitkan oleh PPAT merupakan akta otentik yang memiliki kekuatan pembuktian yang sempurna. Selain itu, dengan penerbitan akta tersebut juga membantu pemerintah dalam penarikan pajak peralihan hak atas tanah karena tidak boleh dilakukan penandatanganan akta peralihan sebelum pajak peralihan dibayarkan.

Sehingga ketika pemohon tidak dapat membuktikan bukti peralihan kepemilikan tanah karena tidak memiliki atau tidak lengkap maka diganti dengan membuat surat pernyataan tertulis tentang pemilikan dan/atau penguasaan fisik bidang tanah dengan itikad baik. Hal ini sesuai dengan Pasal 22 ayat 2 Permen Agraria No 6 Tahun 2018 yang menyebutkan bahwa "Dalam hal bukti kepemilikan tanah masyarakat tidak lengkap atau tidak ada sama sekali maka dapat dilengkapi dan dibuktikan dengan surat pernyataan tertulis tentang pemilikan dan/atau penguasaan fisik bidang tanah dengan itikad baik oleh yang bersangkutan”.

Surat pernyataan tersebut dibuat oleh Peserta PTSL dengan disaksikan oleh dua orang saksi dari lingkungan sekitar yang tidak memiliki hubungan darah dan dapat dipertanggungjawabkan baik secara perdata maupun pidana. Dalam hal ini itikad baik setiap pemohon merupakan tolak ukur berupa kejujuran yang sulit diidentifikasi secara langsung dan merupakan kesadaran dari setiap pemohon. Surat pernyataan yang menggantikan akta peralihan ini tidak memiliki kekuatan pembuktian yang sempurna seperti akta PPAT karena dibuat sendiri oleh pemohon dengan disaksikan oleh dua orang saksi. Surat tersebut hanya merupakan surat dibawah tangan yang memiliki kekuatan pembuktian lemah bila dibandingkan akta otentik. Sehingga suatu saat dapat dipermasalahkan oleh orang lain yang mampu membuktikan sebaliknya.

Surat pernyataan tersebut harus menyatakan bahwa memang tidak ada pihak yang keberatan atas tanah yang dimiliki dan tidak dalam sengketa, serta menyatakan bahwa tanah tersebut bukan merupakan aset pemerintah dan bukan kawasan hutan. ${ }^{5}$ Surat pernyataan tersebut disaksikan oleh dua orang dan memang dibuat berdasarkan keterangan yang sebenarnya. Sehingga ketika Pemohon ternyata dikemudian hari ditemukan terdapat itikad buruk terhadap kepemilikan tanah tersebut maka akan dikenakan sanksi perdata dan pidana. Sedangkan Kantor Pertanahan Kota Batu tidak akan ikut bertanggung jawab atas hal tersebut.

\footnotetext{
${ }^{5}$ Pasal 22 ayat (4) Peraturan Menteri Agraria dan Tata Ruang/ Kepala Badan Pertanahan Nomor 6 Tahun 2018 tentang Pendaftaran Tanah Sistematis Lengkap.
} 
b. Penundaan Pembayaran Pajak Peralihan Hak Atas Tanah

Pengecualian lainnya yaitu adanya penundaan pembayaran pajak peralihan tanah seperti Bea Perolehan Hak Atas Tanah dan Bangunan (BPHTB) dan Pajak Penghasilan (PPh). Pajak Peralihan HAT merupakan kewajiban setiap pemohon dalam mengalihkan tanahnya. Pasal 33 Permen Agraria 6 Tahun 2018 memberikan ruang kemudahan dalam pelaksanaan PTSL karena masyarakat yang belum mampu untuk membayar PPh dan BPHTB dapat membuat surat pernyataan PPh dan BPHTB terhutang. Kelemahan pasal tersebut yaitu Permen Agraria No 6 Tahun 2018 belum menjelaskan terkait mekanisme penagihan dan jangka waktu penundaan pembayaran pajak tersebut. Pasal 33 hanya menyebutkan bahwa Kepala Kantor Pertanahan wajib menyampaikan daftar PPh dan BPHTB yang terhutang secara periodik dalam waktu 3 bulan kepada Bupati atau Walikota dan apabila terdapat peralihan hak atau perubahan atas buku tanah dan sertifikat tanah hanya dapat dilakukan ketika Pemohon tersebut telah melunasi PPh dan BPHTB yang terhutang tersebut.

Dalam hal ini, Kantor Pertanahan Kota Batu memiliki kewajiban untuk mengirimkan data tersebut kepada Walikota Batu terkait pajak terutang tersebut setiap 3 bulan. Apabila Kepala Kantor Pertanahan Kota Batu tidak tertib administrasi terkait hal pelaporan pajak terutang ini maka Pemerintah Daerah dan Pusat akan mengalami kerugian. Selain itu, perlu adanya aturan yang jelas dan khusus terkait pajak terutang (PPh dan BPHTB terutang) dalam pelaksanaan PTSL sehingga tidak ada pihak-pihak yang dirugikan dikemudian hari.

Pada dasarnya pembiayaan terkait pelaksanaan PTSL telah diatur dalam Surat Keputusan Bersama Menteri ATR/Ka. BPN, Mendagri, dan Menteri Desa, Pembangunan Daerah Tertinggal dan Transmigrasi Nomor 25/SKB/V/2017, Nomor 590-31671A Tahun 2017, Nomor 34 Tahun 2017 tentang Pembiayaan Persiapan Pendaftaran Tanah Sistematis. Pembiayaan yang diatur dalam surat tersebut yaitu utnuk kegiatan penyiapan dokumen, pengadaan patok dan mateari, dan kegiatan operasional petugas kelurahan/desa. Sedangkan biaya BPHTB dan PPh tidak dijelaskan dalam surat tersebut.

Pajak peralihan memang cukup memberatkan masyarakat ketika ada peralihan hak atas tanah. Sehingga, khusus pelaksanaan PTSL sebaiknya terdapat pengecualian terkait pembayaran BPHTB dan PPh terkhusus untuk masyarakat yang kurang mampu. Pemerintah dapat memberikan pengurangan dan/atau keringanan terkait penarikan pajak tersebut bahkan dapat memberikan presentase nol persen terhadap perhitungan pajak. Hal ini dapat dilakukan dengan merevisi SKB 3 Menteri tersebut dengan memberikan pasal khusus terkait perpajakan.

\section{c. Sumber daya manusia yang kurang}

Permasalahan lain yang muncul dalam pelaksanaan PTSL di Kota Batu tersebut yaitu sumber daya manusia. Sumber daya manusia yang terpenting dalam pelaksanaan PTSL yaitu 
Petugas Ukur. Jumlah Petugas Ukur di Kantor Pertanahan Kota Batu yang sedikit dibanding dengan luas tanah di Kota Batu menyebabkan proses pengukuran di Kota Batu berlangsung lama. Berdasarkan wawancara dengan Bu Wira, dapat diketahui bahwa satu tim petugas ukur yang terdiri dari dua orang dapat mengukur lima hingga sepuluh bidang tanah per harinya. Namun ketika letak tanahnya berjauhan maka satu hari hanya bisa mengukur lima bidang tanah. Tanah yang diukur di Kota Batu didominasi oleh tanah yang cukup luas.

Proses pemetaan atau pengukuran, berdasarkan pemaparan Bu Wira, dapat diproyekkan karena sumber daya manusia di Kantor Pertanahan Kota Batu masih sedikit. Kantor Pertanahan Kota Batu dapat memproyekkan pengukuran tersebut dapat diberikan kepada Pihak Ketiga. Pihak ketiga dapat berupa Badan Usaha maupun Perorangan yang telah menjadi surveyor berlisensi. Tugas yang diberikan kepada pihak ketiga ini sejak pengukuran hingga menggambar peta bidang. Namun hal ini tidak dilakukan meskipun sumber daya manusia yang sedikit, Kantor Pertanahan Kota Batu masih dapat mengupayakan sendiri tanpa bekerja sama dengan pihak lain.

Sumber daya manusia sebenarnya sudah diantisipasi oleh Pemerintah dengan menerbitkan Peraturan Menteri ATR/ Ka. BPN Nomor 11 tentang Surveyor Kadaster Berlisensi. Namun, juga dapat memberdayakan dan memberikan kewenangan kepada Pegawai Tidak Tetap yang terdapat di lingkungan Badan Pertanahan Republik Indonesia yang sebenarnya memiliki kompetensi dan kemampuan lebih dalam pengukuran tanah. Selain itu, sebenarnya dapat melibatkan pihak lain yang berlatar belakang pengukuran tanah.

d. Tanah Absentee dan Tanah Terlarang di Kota Batu

Masalah lain yang ditemukan dalam pelaksanaan PTSL yaitu terdapat tanah absentee dan tanah yang bersengketa. Tanah absentee merupakan tanah pertanian yang dimiliki oleh perorangan yang tempat tinggalnya tidak dalam satu kecamatan. Pasal 10 UUPA telah menyebutkan bahwa tanah pertanian harus dikerjakan atau diusahakan secara aktif oleh pemiliknya sendiri. Ketika suatu tanah termasuk dalam tanah absentee maka wajib dialihkan kepada orang lain yang masih tinggal dalam satu kecamatan paling lambat 6 bulan sejak pemilik tanah tersebut pindah. Selain tanah absentee ada juga tanah terlantar yang ada di Kota Batu. Kepemilikan tanah di Kota Batu terkadang hanya sebagai investasi dan pemegang hak ternyata tidak berdomisili di Kota Batu. Akibat adanya tanah absentee dan tanah terlantar inilah, pengukuran tanah di Kota Batu dalam PTSL menjadi terhambat karena pemilik yang tidak ada sehingga kesulitan untuk melakukan pengukuran tanah dalam hal penentuan batas.

Tanah yang belum bersertifikat belum memiliki batas tanah sehingga kehadiran pemilik tanah sangat diperlukan. Petugas ukur akan mengukur tanah sesuai dengan petunjuk pemilik tanah dan pihak-pihak yang tanahnya saling berbatasan. Sebelum kegiatan pengukuran dan penetapan batas maka pemilik dan pihak yang berbatasan akan menandatangani surat 
pernyataan terkait batas-batas tanah yang sebelumnya ditentukan atas kesepakatan bersama. Penentuan batas ini terkait dengan asas kontradiktur delimitasi yang sebenarnya sudah diatur dalam Pasal 17 ayat (1) PP 24 Tahun 1997 yang menyebutkan bahwa "Untuk memperoleh data fisik yang diperlukan bagi pendaftaran tanah, bidang-bidang tanah yang akan dipetakan diukur, setelah ditetapkan letaknya, batas-batasnya dan menurut keperluannya ditempatkan tanda-tanda batas di setiap sudut bidang tanah yang bersangkutan."

Penetapan batas-batas tersebut merupakan kesepakatan oleh Pemilik tanah dan pihakpihak yang berbatasan. Asas kontradiktur delimitasi merupakan asas yang digunakan sebagai tahap awal pekerjaan pengukuran tanah yang dilakukan oleh Pemilik tanah dan pemilik tanah yang berbatasan. Apabila ada pihak yang tidak sepakat atas penetapan batas tersebut maka akan dilakukan penetapan batas sementara yang telah diatur dalam Pasal 19 PP 24 Tahun 1997. Selain ketidakhadiran pemilik tanah, asas ini tidak dapat berjalan dengan baik karena pemegang hak atas tanah tidak memelihara batas tanah dengan baik dan adanya sengketa batas tanah, sengketa keluarga, atau tetangga dan sengketa tanah yang sudah masuk dalam ranah pengadilan.

Pemerintah seharusnya lebih bertindak jelas terhadap penertiban tanah absentee dan tanah terlantar. Tanah absentee telah diatur dalam UU Nomor 56 Tahun 1960 yang menjelaskan bahwa tanah absentee dan tanah yang melebihi batas maksimum direncanakan untuk didistribusikan kepada kelompok masyarakat yang tidak memiliki tanah. Sedangkan untuk penertiban tanah terlantar juga sudah diatur dalam PP Nomor 11 Tahun 2010. Namun, kedua aturan tersebut belum bisa berjalan dengan baik karena kedudukan pemegang hak atas tanah kuat karena memiliki sertifikat hak atas tanah.

\section{E. PENUTUP}

Desa yang mengikuti PTSL Kota Batu tahun 2018 yang menjadi tempat penelitian yaitu Desa Oro-Oro Ombo dan Kelurahan Dadaprejo. Kedua wilayah tersebut bekerja sama dengan Kelompok Masyarakat untuk mengumpulkan data dari masyarakat. Pelaksanaan PTSL di Desa Oro-Oro Ombo dan Kelurahan Dadaprejo memiliki persamaan yaitu pihak Desa mensosialisasikan PTSL bersama Kantor Pertanahan Kota Batu, membuatkan Surat Keputusan penunjukkan pihak pelaksana PTSL di masing-masing wilayah, membuatkan kelengkapan administrasi, dan sebagai mediator ketika terjadi suatu permasalahan dalam pelaksanaan PTSL. Hal ini juga menjelaskan bahwa peran yang dimiliki Kantor Desa ataupun Kelurahan hanya sebagai pelengkap, sedangkan yang memiliki peran penting dalam kelancaran PTSL yaitu Kelompok Masyarakat dalam pengumpulan data. 
Pelaksanaan PTSL di Kota Batu ditemukan masalah yaitu obyek tanah dalam penjaminan di perbankan, jangka waktu pengumuman data fisik dan yuridis yang ternyata bertentangan dengan PP 24 Tahun 1997, Surat Pernyataan Kepemilikan dengan Itikad Baik sebagai pengganti akta peralihan yang merupakan akta dibawah tangan, penundaan pembayaran Pajak Peralihan Hak Atas Tanah, sumber daya manusia yang kurang khususnya petugas ukur yang menyebabkan lambatnya proses PTSL, masih terdpat tanah Absentee dan tanah terlantar di Kota Batu yang mengakibatkan pengukuran bidang tanah tidak dapat berjalan dengan lancar karena pemilik tanah tidak berada ditempat untuk menunjukkan batas dan memberikan persetujuan batas tanah.

\section{DAFTAR PUSTAKA}

Achmad Shodiki, Pembaruan Hukum Pertanahan Nasional Reforma Agraria, Jakarta: 2001

Ady Kusnadi Dkk, Penelitian Tentang Efektifitas Peraturan Perundang-Undangan Larangan Tanah Absentee, Badan Pembinaan Hukum Nasional Departemen Kehakiman dan Hak Asasi Manusia Republik Indonesia, Jakarta: 2001

Badan Pusat Statistik Kota Batu, Statistik Daerah Daerah Kota Batu 2016, Batu: 2016

Benhard Limbong, Politik Pertanahan, Margaretha Pustaka, Jakarta: 2014

Dian Aries Mujiburohman, Potensi Permasalahan Pendaftaran Tanah Sistematik Lengkap (PTSL), Bhumi, Volumen 4 Nomor 1 Mei 2008

Gunawan Wiradi, Reforma Agraria: Perjalanan yang belum berakhir, Insist Pers, KPA dan Pustaka Pelajar, Yogyakarta; 2000

, Seluk Beluk Masalah Agraria: Reforma Agraria dan Penelitian Agraria, Sajogyo Institute dan Sekolah Tinggi Pertanahan Nasional, Yogyakarta: 2009

M. Bakri, Pengantar Hukum Indonesia, Sistem Hukum Indonesia Pada Era Reeformasi, UB Press, Malang: 2011.

Muhammad Ilham Arisaputra, Reforma Agraria Di Indonesia, Sinar Grafika, Jakarta: 2015.

P. Sunaryo Basuki, Dkk., Analisis dan Evaluasi Hukum Tentang Batas Pemilikan Tanah Di Daerah Perkotaan, Badan Pembinaan Hukum Nasional Departemen Kehakiman RI; 1999

Peraturan Menteri Agraria dan Tata Ruang/Kepala Badan Pertanahan Nasional Republik Indonesia Nomor 6 Tahun 2018 tentang Pendaftaran Tanah Sistematis Lengkap.

Peraturan Pemerintah Nomor 24 Tahun 1997 tentang Pendaftaran Tanah

Peter Mahmud Marzuki, Penelitian Hukum, Kencana, Jakarta. 2010 
Sudargo Gautama dan Ellyda T. Soetijarto, Tafsiran Undang-Undang Pokok Agraria (1960) dan Peraturan-Peraturan Pelaksanannya (1996), Cetakan ke-sepuluh, Citra Aditya Bakti, Bandung; 1997

Supriadi, Hukum Agraria, Sinar Grafika, Jakarta: 2007

Undang-Undang Nomor 5 Tahun 1960 tentang Pokok-Pokok Agraria

Yunizar Wahyu Tristanto, Harmonisasi Regulasi Kepemilikan Tanah Pertanian Secara Absentee

Bagi Pegawai Negeri Dalam Program Landreform, Legality : Jurnal Ilmiah Hukum, Vol.26, No.2, September 2018-Februari 2019, hlm. 281-293 